\title{
VILLANYCSENGŐ ELEKTROMECHANIKAI MODELLJE
}

\author{
Szabó Tamás \\ egyetemi docens, Miskolci Egyetem, Szerszámgépészeti és Mechatronikai Intézet, \\ Robert Bosch Mechatronikai Intézeti Tanszék \\ 3515 Miskolc, Miskolc-Egyetemváros, e-mail: szabo.tamas@uni-miskolc.hu \\ Rónai László \\ tanársegéd, Miskolci Egyetem, Szerszámgépészeti és Mechatronikai Intézet, \\ Robert Bosch Mechatronikai Intézeti Tanszék \\ 3515 Miskolc, Miskolc-Egyetemváros, e-mail: ronai.laszlo@uni-miskolc.hu
}

\begin{abstract}
Absztrakt
A cikk egy villanycsengö elektromechanikai modellezésével foglalkozik. A rendszer aktuátora egy elektromágnes, amely egy rugalmas kalapács szerkezetet gerjeszt. A szerkezet müködését az áramerösség és elmozdulás változókkal három egyenletrendszer irja le. Az első elektromechanikai jellegü, a második egy, a kalapács szabad mozgását írja le, a harmadik a kalapács csengövel való rugalmas ütközését modellezi. Az egyenletek alapján szimulációs program készült Scilab rendszer alatt, amely a kalapács elmozdulását és az áramerösséget ábrákkal szemlélteti.
\end{abstract}

Kulcsszavak: villanycsengö, elektromechanikai modell, szimuláció

\begin{abstract}
This article deals with electromechanical modeling of an electric bell. The actuator of the system is an electromagnet that excites a flexible hammer structure. The operation of the structure with the current and displacement variables is described by three systems of equations. The first one describes an electromechanical one, the second one describes the free movement of the hammer, and the third one is writing the elastic collision of the hammer with a bell. Based on the equations, a simulation program was developed under Scilab system, the displacement of the hammer and the current are illustrated by curves.
\end{abstract}

Keywords: electric bell, electromechanical model, simulation

\section{Bevezetés}

A villanycsengő egy elektromechanikai szerkezet, amelyet egy elektromágnes a rendszer aktuátoraként gerjeszti, a mechanikai szerkezet mozgását az [1] irodalom vizsgálta. Az elektromágnes magafelé húzza a rugalmasan rögzített kalapácsot, hogy az a csengő harangjának ütközzön. A kalapács egyben egy kapcsolóként is szolgál, a nyugalmi helyzethez képest adott távolságra érve leválasztja a tekercsről a feszültségforrást. Ezután tehetetlenségénél fogva tovább lendül, majd a csengővel való ütközés után pedig visszapattan. Amikor a kalapács visszaér az elektromos érintkezőhöz a mozgás irányával ellentétes elektromágneses erő hatására lelassul és újra a harang felé indul meg. Ez a ciklikus mozgás egy másodperc alatt többször is megismétlödik.

Egy elektromechanikai feladat megfogalmazható általános koordinátákkal, azaz az elmozdulással és az elektromos töltéssel, vagy általános potenciálokkal, azaz az impulzussal és a fluxussal, illetve ezen változók vegyes kombinációival is [2], [3]. Általánosságban elmondható, hogy általános koordinátákkal 
természetesebben, könnyebben lehet elóállítani a rendszert leíró differenciálegyenletrendszert, mert a mechanikai feladatban a kinematikai perem- és illesztési feltételeket, illetve a villamos feladatban a Kirchhoff- féle csomóponti törvényt kézenfekvőbb teljesíteni, mint a mozgásegyenletet a dinamikai feladatban és a hurok törvényt a villamos feladatban.

Jelen cikk az elektromos csengő elektromechanikai egyenleteit általános koordinátákkal tárgyalja, vagyis a kalapács elmozdulásával, a tekercsen időegység alatt áthaladó töltéssel, azaz az áramerősséggel. A 2. fejezet a csengő elektromechanikai modelljét származtatja a másodfajú Lagrange egyenletből. A 3. fejezet ismerteti a szimulációs eredményeket egy adott elektromos és mechanikai paraméterekkel rendelkező egyenáramú csengőre. A 4. fejezet tartalmazza az összefoglaló megállapításokat.

\section{Elektromos csengő matematikai modellje}

Az elektromos csengő modelljének vázlatát az 1. ábra szemlélteti. A rendszer áramköri elemei az $L$ induktivitás, az $R$ ohmos ellenállás, az $S$ kapcsoló, illetve az $U_{0}$ feszültségforrás. Az áttekinthetőség kedvéért a mechanikai rezgőrendszer elemei közül az ábra csak az $m$ kalapács és $m_{r}$ rúd tömegét, valamint a $k_{1}$ és $k_{2}$ rugómerevségeket tünteti fel, de nem tartalmazza az $r_{1}$ és $r_{2}$, rugókkal párhuzamosan bekötött csillapításokat. A kalapács és a harang viszkorugalmas ütközését modellező $k_{c}$ rugómerevséget, azaz büntetôparamétert és $r_{c}$ csillapítást sem vázoltuk. Megjegyezzük, hogy a rudat valójában nem csuklóval, hanem befalazással szokás rögzíteni, a $k_{1}$ rugómerevség szimbolikusan jelöli a rugalmas rúd hajlítási merevségét $\left(k_{1}=3 I E / L^{3}\right)$ [4] nyugalmi helyzetben, míg $k_{2}$ az elektromos érintkező merevségét reprezentálja. Ezzel a feltételezéssel a mechanikai rezgőrendszer egy szabadságfokúnak tekinthető. A $k_{1}$ és $k_{2}$ rugók nyugalmi helyzetben egymásnak ellenfeszülnek. A rúd mozgása során $k_{2}$ rugó nem mindig érintkezik, elváláskor szakítja az áramkört. Az érintkezéskor a $k_{2}$ rugón keresztül záródik az áramkör. Ebből adódik, hogy a mechanikai rezgőrendszer nemlineáris jellegü, hiszen szakaszonként különböző merevségű rugók múködnek.

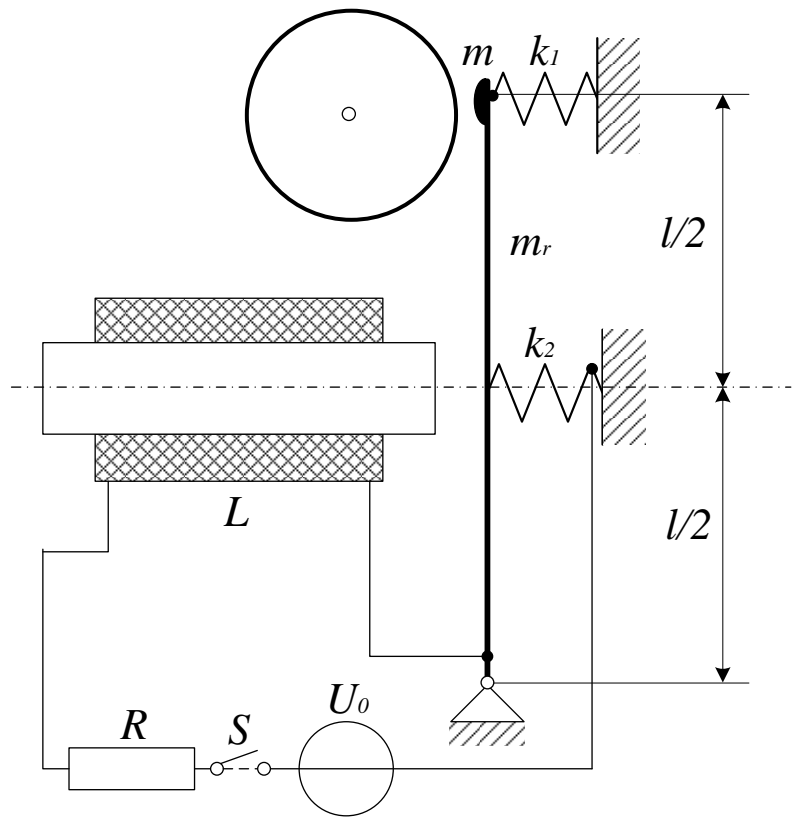

1. ábra. A csengö sematikus vázlata 
Az elektromechanikai rendszerek tartalmaznak konzervatív és nem konzervatív elemeket. A konzervatív elemek energiáit az $\mathcal{L}$ Lagrange függvénnyel fejezhetjük ki:

$$
\mathcal{L}=T^{*}+W_{m}^{*}-U_{p}-W_{e},
$$

ahol rendre $T^{*}, W_{m}^{*}, U_{p}$ és $W_{e}$ jelentik a kiegészítỏ kinetikai energiát, a kiegészítő mágneses energiát, a potenciális energiát és a villamos energiát.

A nem konzervatív tagokhoz virtuális munka rendelhető az alábbiak szerint:

$$
\overline{\delta W}_{n c}=U_{q} \delta q+Q_{x} \delta x,
$$

ahol $U_{q}$ a nem konzervatív tag feszültsége, $Q_{x}$ pedig az általánosított erőt jelenti. Mindkét tag elöjelét az határozza meg, hogy a rendszer energiáját növeli vagy disszipálja. A $\delta q$ és a $\delta x$ rendre jelölik a töltés és az általánosított elmozdulás virtuális megváltozásait.

Az (1) és (2) kifejezések segítségével felírható az elektromechanikai rendszer másodfajú Lagrange egyenletei:

$$
\begin{aligned}
& \frac{d}{d t}\left(\frac{\partial \mathcal{L}}{\partial \dot{q}}\right)-\frac{\partial \mathcal{L}}{\partial q}=U_{q} \\
& \frac{d}{d t}\left(\frac{\partial \mathcal{L}}{\partial \dot{x}}\right)-\frac{\partial \mathcal{L}}{\partial x}=Q_{x} .
\end{aligned}
$$

Az 1. ábra átláthatósági megfontolások miatt nem tünteti fel a kalapács érintkezőtől való elválási- és a haranggal való ütközési helyeit. A továbbiakban $x_{1}$ a kalapács $k_{2}$ rugótól való elválásának elöjeles helyét adja meg, míg $x_{2}$ a kalapács ütközésének pozícióját definiálja.

A kalapács $x_{1}, x_{2}$ helyzeteitől függően három fázist különböztethetünk meg. A I. első esetben $(x-$ $\left.x_{1}>0\right)$ amíg a $k_{2}$ rugó érintkezésben van, addig az elektromágnest gerjesztjük. A II. második állapotnál a $k_{2}$ rugó elválik a kalapácstól $\left(x-x_{1}<0\right.$ és $\left.x-x_{2}>0\right)$, ekkor az áramkör megszakad, így a kalapács és a $k_{1}$ rugó rugalmas rendszert alkotva végzi mozgását. A III. harmadik, rendkívül rövid fázisban a kalapács és a harang rugalmas ütközése játszódik le $\left(x-x_{2}<0\right)$. Ez a három fázis egymás után alternálva ismétlődik meg.

I. fázis összefüggései:

$$
T^{*}=\frac{1}{2}\left(m+\frac{m_{r}}{3}\right) \dot{x}^{2}, \quad U_{p}=\frac{1}{2}\left(k_{1}+\frac{k_{2}}{4}\right) x^{2}, \quad W_{m}^{*}=\frac{1}{2} L(x) \dot{q}^{2}, \quad W_{e}=0,
$$

ahol az elektromágnes induktivitását a hely függvényében közelíthetjük [3] szerint

$$
L(x)=\frac{L_{0}}{1-\left(x+x_{1}\right) / 2 h},
$$

az $L_{0}$ kezdeti induktivitás és a $h$ paraméter függvényében.

A nem konzervatív tagok virtuális munkája:

$$
\overline{\delta W}_{n c}=U_{0} \delta q-R \dot{q} \delta q-r_{1} \dot{x} \delta x-r_{2} \frac{\dot{x}}{2} \frac{\delta x}{2} .
$$

A (3), (4) alapján (5)-(7) figyelembevételével a rendszerre vonatkozóan az alábbi differenciálegyenletek állnak elő 


$$
\begin{gathered}
L(x) \ddot{q}+R \dot{q}+L^{\prime}(x) \dot{q} \dot{x}=U_{0}, \\
\left(m+\frac{m_{r}}{3}\right) \ddot{x}+\left(r_{1}+\frac{r_{2}}{4}\right) \dot{x}+\left(k_{1}+\frac{k_{2}}{4}\right) x=\frac{1}{2} L^{\prime}(x) \dot{q}^{2} .
\end{gathered}
$$

II. fázis összefüggései:

$$
T^{*}=\frac{1}{2}\left(m+\frac{m_{r}}{3}\right) \dot{x}^{2}, \quad U_{p}=\frac{1}{2} k_{1} x^{2}, \quad W_{m}^{*}=0, \quad W_{e}=0 .
$$

A nem konzervatív tagok virtuális munkája:

$$
\bar{\delta}_{n c}=-r_{1} \dot{x} \delta x .
$$

A (3), (4) alapján (10), (11) figyelembevételével a rendszer differenciálegyenlete:

$$
\left(m+\frac{m_{r}}{3}\right) \ddot{x}+r_{1} \dot{x}+k_{1} x=0 .
$$

III. fázis összefüggései:

$$
T^{*}=\frac{1}{2}\left(m+\frac{m_{r}}{3}\right) \dot{x}^{2}, \quad U_{p}=\frac{1}{2} k_{1} x^{2}+\frac{1}{2} k_{c}\left(x-x_{2}\right)^{2}, \quad W_{m}^{*}=0, \quad W_{e}=0,
$$

A nem konzervatív tagok virtuális munkája:

$$
\bar{\delta}_{n c}=-\left(r_{1}+r_{c}\right) \dot{x} \delta x .
$$

A (3), (4) alapján (13), (14) figyelembevételével a differenciálegyenletek:

$$
\left(m+\frac{m_{r}}{3}\right) \ddot{x}+\left(r_{1}+r_{c}\right) \dot{x}+k_{1} x+k_{c}\left(x-x_{2}\right)=0 .
$$

A folyamat indítása kezdetén feltételezzük, hogy $x(0)=0, q(0)=0$ és $\dot{q}(0)=0$. Az egymást váltó három fázis kezdeti értékei megegyeznek az előtte lévő fázis végső elmozdulás és áramerősség menynyiségeivel. Továbbá megjegyezzük, hogy az I. fázis végén az áramkör megszakadásával a $q$ és $\dot{q}$ gyakorlatilag zérus értékủvé válnak.

Megjegyezzük, hogy a mechanikai rezgéstani egyenletek ugyan külön-külön lineárisnak tekinthetők, ebből adódóan egy ciklus végrehajtása nemlineáris jellegü lesz.

\section{Numerikus számítások}

A 2. fejezetben elöállított egyenletek alapján Scilab szabadon letölthető rendszer alatt egy szimulációs program kifejlesztése történt meg. A vizsgált villanycsengő adatai a következők: $L_{0}=0,5 \mathrm{mH}, h=$ $0,001, x_{1}=1 \mathrm{~mm}, x_{2}=1,5 \mathrm{~mm}, R=5 \Omega, U_{0}=6 \mathrm{~V}, m_{r}=2 \mathrm{dkg}, m=3,3 \mathrm{~g}, k_{1}=25 \mathrm{~N} / \mathrm{m}, k_{2}=$ $20 \mathrm{~N} / \mathrm{m}, k_{c}=50 \mathrm{~N} / \mathrm{mm}, r_{1}=0,01 \mathrm{Ns} / \mathrm{m}, r_{2}=0,008 \mathrm{Ns} / \mathrm{m}, r_{c}=0,02 \mathrm{Ns} / \mathrm{mm}$.

Az áramerősségre és a kalapács elmozdulására kapott eredményeket rendre a 2. és a 3. ábrák szemléltetik.

A 2. ábra alapján megállapíthatjuk, hogy a villanycsengő kalapácsa $1 s$ alatt 25 -ször üti meg a harangot. Az áramerősség csúcsértéke az $R$ ellenállás és az $U_{0}$ kapocsfeszültség értékeinek megfelelően $1,2 A$-re adódott. 
A 3. ábra a kalapács elmozdulását mutatja, ahol kék szaggatott vonal jelzi az $x_{1}$, azaz az érintkező elválásának a helyét, míg piros szaggatott vonal mutatja az $x_{2}$ vagyis a kalapács és a harang felütközésének pozícióját. Jól megfigyelhető, hogy a kalapács visszapattanása után az elektromágneses erő a kalapácsot lelassítja, majd újból a csengő felé gyorsítja. Továbbá látható, hogy a kalapács felütközése a harangon pillanatszerü rövidséggel történik meg, illetve a kék szaggatott vonal és az elmozdulás függvény metszetének hossza megegyezik a 2. ábrán látható áramerősség impulzusok hosszával. Az elmozdulás függvény állandósult állapotban ugyan periodikusnak tekinthető, de nem harmonikus függvény, amely a feladat nemlineáris jellegéböl adódik.

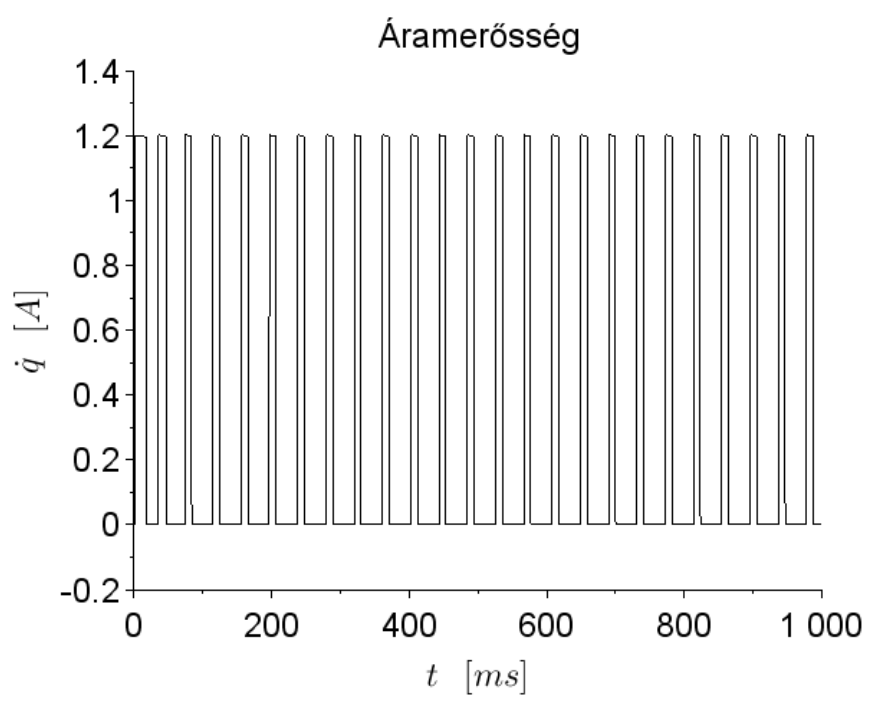

2. ábra. Az áramerösség változása az idö függvényében

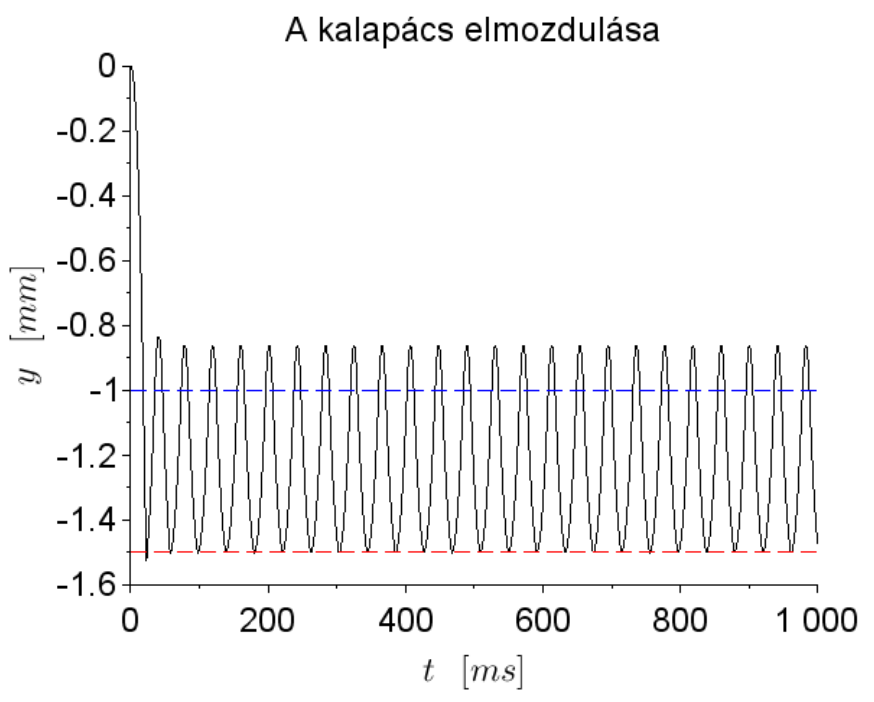

3. ábra. A kalapács elmozdulása az idö függvényében 


\section{4. Összefoglalás}

A cikk egy elektromos csengő matematikai modellezésével és szimulációjával foglalkozott. A mechanikai rezgőrendszer nemlineáris jellege a szakaszonként különböző merevségü rugókból és csillapításokból adódik. A Lagrange egyenlet felhasználásával általánosított koordinátákkal, azaz elektromos töltéssel és elmozdulással levezetésre került az elektromechanikai rendszer differenciálegyenletrendszere három különböző fázisra osztva. A mechanikai rendszer modellje egy szabadsági fokkal rendelkezik. A szimulációs eredmények megerösítették a gerjesztett rezgést végző rendszer nemlineáris jellegét, mert az elmozdulás függvény láthatóan nem harmonikus. A modell alkalmas a csengő frekvenciájának tervezésére.

\section{Köszönetnyilvánítás}

A cikkben ismertetett kutató munka az EFOP-3.6.1-16-2016-00011 jelü „Fiatalodó és Megújuló Egyetem - Innovatív Tudásváros - a Miskolci Egyetem intelligens szakosodást szolgáló intézményi fejlesztése" projekt részeként - a Széchenyi 2020 keretében - az Európai Unió támogatásával, az Európai Szociális Alap társfinanszírozásával valósul meg.

\section{Irodalom}

[1] Akashi, H., Levy, S.: The motion of an electric bell, The American Mathematical Monthly, Vol. 65, No. 4, 1958, pp. 255-259 https://doi.org/10.1080/00029890.1958.11989179

[2] Szabó, T., Rónai, L.: Generalized displacements and momenta formulations of an electromechanical plunger, Journal of Computational and Applied Mechanics, 2020, pp 1-12 (megjelenés alatt)

[3] Preumont, A.: Mechatronics - dynamics of electromechanical and piezoelectric systems-. Springer., 2006, ISBN-13 978-1-4020-4695-7 (HB)

[4] Égert, J., Jezsó, K.: Mechanika, rezgéstan, Széchenyi István Egyetem, HEFOP 3.3.1-P.2004-090102/1.0, 2006 